Business and Politics in Britain 
Also by Wyn Grant

Government and Industry: a Comparative Analysis of the US,

Canada and the UK

Pressure Groups, Politics and Democracy in Britain

The Political Economy of Industrial Policy

Independent Local Politics in England and Wales

The Dairy Industry: an International Comparison

The CBI (with David Marsh)

The Politics of Economic Policy Making (with Shiv Nath)

Government and the Chemical Industry (with William Paterson and Colin Whitston)

The Political Economy of Corporatism (edited) 


\section{Business and Politics \\ in Britain}

Second Edition

Wyn Grant 
(C) Wynford P. Grant 1987, 1993

All rights reserved. No reproduction, copy or transmission of this publication may be made without written permission.

No paragraph of this publication may be reproduced, copied or transmitted save with written permission or in accordance with the provisions of the Copyright, Designs and Patents Act 1988, or under the terms of any licence permitting limited copying issued by the Copyright Licensing Agency, 90 Tottenham Court Road, London WIP 9HE.

Any person who does any unauthorised act in relation to this publication may be liable to criminal prosecution and civil claims for damages.

First published 1987 by

THE MACMILLAN PRESS LTD

Houndmills, Basingstoke, Hampshire RG21 2XS

and London

Companies and representatives

throughout the world

ISBN 978-0-333-59331-8

ISBN 978-1-349-22875-1 (eBook)

DOI 10.1007/978-1-349-22875-1

A catalogue record for this book is available

from the British Library.

First edition reprinted 1991

Second edition 1993

$\begin{array}{rrrrrrr}8 & 7 & 6 & 5 & 4 & 3 & 2 \\ 03 & 02 & 01 & 00 & 99 & 98 & 97\end{array}$


For Sophia, Rosalind and Amelia 


\section{Contents}

Preface $\quad$ xi

1 Introduction 1

Questions of definition 3

Economic globalisation 4

The politics of production and of collective consumption 6

The comparative context 9

A typology of business-government relations 13

$\begin{array}{ll}\text { The political weakness of business } & 18\end{array}$

2 The Power of Business 21

Pluralism $\quad 21$

Corporatism 28

Business as a privileged interest 32

The perspectives: an assessment 38

3 Government and Business 46

The policy relationship $\quad 47$

The structure of government 51

Government as a regulator $\quad 48$

Government as a customer $\quad 63$

4 Banks and the Financial Sector 66

Finance and industry $\quad 69$

The political influence of the financial sector 73

The Bank-Treasury relationship $\quad 76$

Sectoral financial associations $\quad 78$

$\begin{array}{ll}\text { Conclusions } & 81\end{array}$ 
5 Large Firms and the Political Process

Forms of political activity by firms $\quad 87$

Government relations divisions $\quad 89$

The limitations of the government relations function $\quad 96$

$\begin{array}{ll}\text { Political consultants } & 99\end{array}$

6 Business Associations $\quad 104$

Explaining the pattern of business associability 105

The CBI: its strengths and weaknesses $\quad 110$

The CBI's competitors 116

Small business associations $\quad 122$

Conclusions 124

7 Business and Party Politics 125

The limits of the literature 125

The difficult relationship between the Conservative

$\begin{array}{ll}\text { Party and business } & 127\end{array}$

The Labour Party: a disappointed suitor $\quad 134$

Business persons in politics $\quad 140$

Business funding of the Conservative Party 141

$\begin{array}{ll}\text { Conclusions } & 145\end{array}$

8 Business Associations and Public Policy 147

The privatisation of public policy 148

Self-regulation in the security industry $\quad 150$

Statutory self-regulation of financial services $\quad 151$

$\begin{array}{ll}\text { The dairy sector } & 155\end{array}$

Training policy 159

Models of business involvement in public policy formation

9 Business Interests and the European Community 166

How business seeks to influence the EC 169

Targets of representation $\quad 185$

$\begin{array}{ll}\text { Social partnership } & 189\end{array}$

10 Conclusions 193

Changes in business-government relations $\quad 195$

$\begin{array}{ll}\text { Constitutional change } & 199\end{array}$

Living with the company state 201 
Guide to Further Reading

205

Bibliography

208

Index

219 


\section{Preface}

It is now over twenty years since David Marsh and I travelled as postgraduate students from Exeter to Bristol to interview the regional office of the Confederation of British Industry for an article on that organisation we were writing to fill a puzzling gap in the political science literature. That was the start of what has proved to be an enduring interest in the relationship between business and politics, most recently extended to Russia and East-Central Europe. Over the past twenty years, I have acquired so many intellectual debts that it would be impossible to acknowledge them all. For the second edition of this book, the Nuffield Foundation awarded me a grant to conduct further interviews with business persons, business association officials, civil servants and others in London and Brussels. It was pleasant to meet some long established contacts again, some now in much more senior positions than when I first interviewed them, but also to meet some of the new participants in the world of business-government relations.

The first edition of this book was stimulated by my participation in a major international comparative project, co-ordinated by Wolfgang Streeck and Philippe Schmitter, on the organisation of business interests. I have continued to keep in contact with many of the participants in this project who have formed an informal network of individuals with broad interests in the area of the relationship between business and government. The study of business-government relations is a growing subject all over the world, and I am grateful to the academics and business persons who have sent me books, articles and papers they have written in the area.

The whole book has been thoroughly revised, but one of the chapters in the book that has required particularly extensive re-writing is that on the European Community, and I am grateful to Mike Cockburn and Jane Sargent for their extensive and helpful comments on earlier versions of this chapter. They bear no responsibility for its contents. 
The University of Warwick has continued to provide an excellent intellectual environment for work concerned with business and government. I am particularly grateful to my colleagues in the Department of Politics and International Studies for their support and encouragement which has enabled me to combine continuing to research and write with my role as departmental chair. Special thanks are due to Professor Barry Buzan for his good advice and to the department's secretaries: Iris Host, Dorothy Foster and Linda Freeman.

Last but not least, thanks are due to my wife, Maggie, and to Sophia, Rosalind and Amelia for their tolerance, common sense and good humour. It is easy to become too preoccupied with large firms, and Ros's job as a junior manager in a small business has helped me to keep in mind the special challenges and problems facing smaller businesses.

WYN GRANT

Leamington Spa 